\title{
LEARNING CYCLE 5E TERHADAP KEMAMPUAN KOMUNIKASI MATEMATIS PESERTA DIDIK
}

\author{
Karina Pekasih Dewi Wulandari ${ }^{1}$, Retno Marsitin $^{2}$, Tri Candra Wulandari ${ }^{3}$ \\ 1,2,3 Pendidikan Matematika, Universitas Kanjuruhan Malang s \\ karina.dewi1327@yahoo.com \\ mars_retno@unikama.ac.id \\ fikri.chan@unikama.ac.id
}

\begin{abstract}
Abstrak: Kemampuan komunikasi matematis dapat dikembangakan melalui penerapan model pembelajaran yang tepat. Salah satunya menggunakan model pembelajaran Learning Cycle 5E. Penelitian ini bertujuan untuk mengetahui pengaruh model pembelajaran Learning Cycle 5E terhadap kemampuan komunikasi matematis peserta didik di SMP Kartika IV-9 Malang. Sampel penelitian adalah kelas VII C dan VII D yang masing-masing berjumlah 31 peserta didik. Jenis penelitian adalah kuasi eksperimen. Analisis data berupa uji validitas dan uji reliabilitas, uji normalitas, uji homogenitas serta uji hipotesis. Pengujian hipotesis menggunakan uji Independent Sample T-Test. Hasil penelitian menujukkan bahwa pengujian hipotesis diperoleh nilai signifikansi $0,000<0,05$ dan rata-rata nilai kemampuan komunikasi matematis peserta didik dengan model pembelajaran Learning Cycle 5E adalah 61,49serta perlakuan yang diberikan pada peserta didik dengan menggunakan model pembelajaran langsung adalah 39,39. Kesimpulan penelitian ini yaitu terdapat pengaruh model pembelajaran Learning Cycle 5E terhadap kemampuan komunikasi matematis peserta didik di SMP Kartika IV-9 Malang.
\end{abstract}

Kata Kunci: Learning Cycle 5E; Komunikasi Matematis.

\section{Pendahuluan}

Pendidikan dapat ditempuh melalui jalur formal yaitu sekolah. Triatna (2016:27) mengemukakan bahwa sekolah merupakan pendidikan dalam bentuk lembaga yang menyelenggarakan program pendidikan untuk mengembangkan potensi peserta didik sesuai dengan tahapan dan perkembangannya. Sekolah pasti tidak lepas dari proses belajar mengajar. Proses belajar mengajar yang dilakukan di sekolah lebih sering disebut dengan pembelajaran. Dimyati (Susanto, 2016:186), menyatakan bahwa pembelajaran adalah kegiatan guru secara terprogram dalam desain instruksional untuk membuat peserta didik belajar secara aktif, yang menekankan pada penyediaan sumber belajar. Sugihartono (Irham, 2014:19) menyatakan bahwa pendidikan adalah usaha sadar dan terencana yang dilakukan oleh pendidik untuk mengubah tingkah laku manusia, baik secara individu maupun kelompok untuk mendewasakan manusia tersebut melalui proses pengajaran dan pelatihan.

Pembelajaran matematika adalah suatu proses belajar mengajar yang dibangun oleh guru untuk mengembangkan kreativitas berpikir peserta didik yang dapat meningkatkan kemampuan berpikir peserta didik, serta dapat meningkatkan kemampuan mengkonstruksi pengetahuan baru sebagai upaya meningkatkan penguasaan yang baik terhadap materi matematika (Susanto, 2016:186). Tujuan pembelajaranmatematika (NCTM, 2000) yaitu: (1) belajar untuk berkomunikasi; (2) belajar untuk bernalar; (3) belajar untuk memecahkan masalah; (4) belajar untuk mengaitkan ide; dan (5) belajar untuk mempresentasikan ide-ide. Salah 


\section{Pi:Mathematics

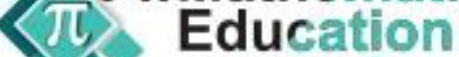 \\ Journal}

satu dari tujuan pembelajaran matematika yang dirumuskan oleh NCTM di atas adalah belajar berkomunikasi, dimana yang dimaksud adalah bukan hanya sekedar menyatakan pendapat secara verbal maupun nonverbal tetapi berkomunikasi secara matematis.

Komunikasi dalam pembelajaran tidak hanya berlangsung satu arah dari guru ke peserta didik saja tetapi dari peserta didik ke guru dan dari peserta didik ke peserta didik. Sukmadinata (dalam Esny, 2015) mengemukakan bahwa komunikasi dibagi menjadi dua yaitu komunikasi lisan dan komunikasi tertulis. Komunikasi lisan yaitu interaksi belajar mengajar berintikan penyampaian informasi berupa pengetahuan utama dari guru kepada peserta didik, sedangkan komunikasi tertulis adalah interaksi belajar mengajar berintikan penyampaian informasi berupa pengetahuan secara tertulis.

\section{Komunikasi}

matematis merupakan suatu cara peserta didik untuk mengungkapkan ide-ide matematika mereka baik secara lisan, tertulis, gambar, diagram, menggunakan benda, menyajikan dalam bentuk aljabar, atau menggunakan simbol matematika (NCTM, 2000). Sumarmo (2010) menyatakan bahwa komunikasi matematis antara lain: (1) menyatakan situasi, gambar, diagram, atau benda nyata ke dalam bahasa, simbol, ide, atau model matematik, (2) menjelaskan ide, situasi, dan relasi matematika secara lisan atau tulisan, (3) mendengarkan, berdiskusi, dan menulis tentang matematika, (4) membaca dengan pemahaman suatu represntasi matematika tertulis, dan (5) mengungkapkan kembali suatu uraian atau paragrap matematika dalam bahasa sendiri.Ross (dalam Fatonah, 2017: 8-9) mengidentifikasi indikator kemampuan komunikasi matematis secara tertulis, yaitu sebagai berikut: (a) Menggambarkan situasi masalah dan menyatakan solusi masalah menggunakan gambar, bagan, tabel, atau penyajian secara aljabar; (b) Menyatakan hasil dalam bentuk tulisan; (c) Menggunakan representasi menyeluruh untuk menyatakan konsep matematika dan solusinya; (d) Membuat situasi matematika dengan menyediakan ide dan keterangan dalam bentuk tulisan; (e) Menggunakan bahasa matematika dan simbol secara tepat.

Komunikasi matematis dalam pembelajaran matematika memegang peranan yang sangat penting. Komunikasi menjadi bagian yang esensial dari matematika dan pendidikan matematika(Marsitin, 2015). Komunikasi menjadi bagian yang penting dalam keberhasilan proses pembelajaran, hal ini kurang sesuai dengan fakta di SMP Kartika IV-9 Malang bahwa 75\% peserta didik masih kesulitan memahami maksud dari soal,yang dapat dilihat ketika pembelajaran di kelas masih sering peserta didik menanyakan maksud dari soal yang terdapat pada buku matematika, kesulitan menentukan apa inti pertanyaan dari soal yang mereka kerjakan, kesulitan menggunakan simbol matematika yang tepat, kesulitan menggambarkan situasi dari permasalahan yang disajikan, menerapkan rumus dan menentukan penyelesaian. Kesulitan-kesulitan yang dihadapi peserta didik tersebut menyebabkan kemampuan komunikasi matematis peserta didik masih kurang maksimal.

Kemampuan komunikasi matematis bisa dikembangkan melalui penerapan model pembelajaran yang tepat. Trianto (2011: 24) menyatakan bahwa suatu model pembelajaran yang baik untuk membantu peserta didik mempelajari keterampilan dasar seperti tabel perkalian atau untuk topik-topik yang banyak berkaitan dengan penggunaan alat. Salah satu model pembelajaran yang dapat digunakan 
untuk meningkatkan kemampuan komunikasi matematis adalah model pembelajaran Learning Cycle 5Eatau siklus belajar.Wena (2014: 170) menyatakan bahwa model pembelajaran Learning Cycle merupakan salah satu model pembelajaran dengan pendekatan konstruktivis yang pada mulanya terdiri atas tiga tahap, yaitu: ekplorasi (exploration), menjelaskan (explanation), dan memperluas (elaboration/extention). Pada proses selanjutnya, tiga tahap siklus tersebut mengalami perkembangan menjadi lima tahap. Lima tahap tersebut yaitu: pembangkitan minat (engagement), eksplorasi/menyelidiki (exploration), menjelaskan (explanation), memperluas (elaboration/extention), dan evaluasi (evaluation).

\begin{tabular}{lrr}
\multicolumn{2}{c}{ Baharuddin \& $\quad$ Wahyuni } \\
(2015:164) menyatakan & bahwa \\
konstruktivisme memahami & hakikat
\end{tabular}
belajar sebagai kegiatan manusia membangun atau menciptakan pengetahuan dengan cara mencoba memberi makna pada pengetahuan sesuai pengalamannya. Trianto (2011: 28) menyatakan bahwa teori konstrutivis ini, satu prinsip yang paling penting dalam psikologi pendidikan adalah bahwa guru tidak hanya sekedar memberikan pengetahuan kepada peserta didik. Peserta didik harus membangun sendiri pengetahuan di dalam benaknya. Pembelajaran berbasis konstruktivisme merupakan belajar artikulasi. Belajar artikulasi adalah proses mengartikulasikan ide, pikiran, solusi. Belajar tidak hanya mengkonstruksikan makna dan mengembangkan pikiran, namun juga memperdalam proses-proses pemaknaan tersebut melalui pengekspresian ide-ide (Suprijono, 2009: 40).

Bilgin (2013) menyatakan bahwa model pembelajaran Learning Cycle banyak diterapkan karena efektifitasnya dievaluasi melalui metode penilaian yang

berguna untuk mengungkapkan integritas konsep dalam pikiran peserta didik. Model pembelajaran Learning Cycle memiliki 5 fase pembelajaran, yaitu engage, explore, explain, expand, dan elaborate. Sejalan dengan pendapat Bilgin, Piaget (Shoimin, 2016:59) menyatakan bahwa model pembelajaran Learning Cycle 5E adalah model pembelajaran yang dilakukan secara bersiklus dan terperinci dengan fase-fase sebagai berikut: (1) Engagement;

Explorations; (3) Explanations;

Elaborations;

Evaluations. Pembelajaran dengan menggunakan model Learning Cycle ditunjang dengan penelitian Lailatus (2016) menyimpulkan bahwa pembelajaran dengan menggunakan model Learning Cycle lebih efektif jika dibandingkan dengan pembelajaran langsung dalam komunikasi matematis. Oleh karena itu, penelitian ini bertujuan untuk mengetahui pengaruh penggunaan model pembelajaran Learning Cycle 5E terhadap kemampuan komunikasi matematis peserta didik di SMP Kartika IV-9 Malang.

\section{Metode Penelitian}

Pendekatan yang digunakan dalam penelitan ini adalah pendekatan kuantitatif. Jenis penelitian adalah penelitian kuasi (quasi experiment) atau eksperimen semu karena tidak mengambil subjek secara utuh (intact group) untuk diberikan perlakuan (treatment). Desain penelitian yang digunakan adalah Nonequivalent control group design, dimana pada desain ini kelompok eksperimen maupun kelompok kontrol tidak dipilih secara random dan dua kelompok tersebut diberikan pretest kemudian diberikan perlakuan, dan terakhir diberikan posttest.

Penelitan ini dilaksanakan di SMP Kartika IV-9 Malang. Populasi yang digunakan dalam penelitian ini adalah 
seluruh peserta didik kelas VII SMP Kartika IV-9 Malang pada semester genap tahun ajaran 2017/2018 yang terdiri dari 6 kelas. Sampel penelitian dengan mengambil sampel kelas VII C sebagai kelas kontrol yang berjumlah 31 peserta didik dan kelas VII D sebagai kelas eksperimen yang berjumlah 31 peserta didik. Instrumen dalam penelitian ini adalah tes. Data diperoleh dari hasil tes yang diberikan pada kedua kelompok sampel dengan pemberian tes yang sama yang dilakukan pada pretest-posttest. Instrumen harus diuji terlebih dahulu sebelum tes diberikan kepada peserta didik.

Pengujian instrumen dilakukan dengan uji validitas dan uji reliabilitas. Uji validitas setiap butir soal menggunakan uji statistik dengan bantuan SPSS 22.0 for Windows, diuji dengan korelasi Pearson Product Moment. Untuk uji reliabilitas menggunakan bantuan program SPSS 22.0 for Windows dengan teknik Cronbach Alpha. Setelah dilakukan pengujian instrumen, selanjutnya adalah uji prasyarat yaitu uji normalitas dan uji homogenitas. Uji normalitas data dilakukan untuk mengetahui apakah data dari populasi berdistribusi normal atau tidak. Uji normalitas yang digunakan adalah uji Kolmogorov-Smirnov Test. Uji homogenitas dilakukan untuk mengetahui apakah kedua kelompok data memiliki varians yang sama (homogen) atau tidak. Setelah dilakukan uji prasyarat, langkah selanjutnya yaitu melakanakan uji hipotesis. Apabila data berasal dari populasi yang berdistribusi normal dan kedua kelompok populasi data bersifat homogen, maka uji hipotesis pada penelitian ini menggunakan Uji Independent Sample T-Test dengan keputusan uji adalah jika nilai signifikansi $>0,05$ maka $\mathrm{H}_{0}$ diterima dan $\mathrm{H}_{1}$ ditolak, sebaliknya jika nilai signifikansi $<0,05$ maka $\mathrm{H}_{0}$ ditolak dan $\mathrm{H}_{1}$ diterima.

\section{Hasil dan Pembahasan}

Data hasil uji coba instrumen selanjutnya akan dilakukan pengujian dengan uji validitas dan uji reliabilitas. Instrumen yang divalidasikan sebelum dilakukan penelitian berupa rencana pelaksanaan pembelajaran, lembar kerja peserta didik, soal pretest dan soal posttest. Validator instrumen dalam penelitian ini adalah dosen Program Studi Pendidikan Matematika Universitas Kanjuruhan Malang dan guru mata pelajaran matematika SMP Kartika IV-9 Malang. Berikut hasil perhitungan validitas soal pretest dengan bantuan SPSS 22.0 for Windows:

Tabel 1. Hasil Perhitungan Soal Pretest

\begin{tabular}{lccc}
\hline $\begin{array}{l}\text { Butir } \\
\text { Soal }\end{array}$ & $\mathrm{r}_{\mathrm{xy}}$ & $\mathrm{r}_{\text {tabel }}(31)$ & Keterangan \\
\hline Soal 1 & 0,831 & 0,355 & Valid \\
Soal 2 & 0,919 & 0,355 & Valid \\
Soal 3 & 0,908 & 0,355 & Valid \\
Soal 4 & 0,926 & 0,355 & Valid \\
\hline
\end{tabular}

Berdasarkan Tabel 1 diatas dapat dilihat bahwa semua soal yang dijadikan pretest memiliki nilai $r_{x y}>r_{\text {tabel }}$ sehingga dapat dikatakan bahwa semua soal valid sehingga soal-soal tersebut layak untuk digunakan. Hasil perhitungan validitas soal posttest disajikan pada Tabel 2 berikut:

Tabel 2. Hasil Perhitungan Soal Posttest

\begin{tabular}{rccc}
\hline $\begin{array}{r}\text { Butir } \\
\text { Soal }\end{array}$ & $\mathrm{r}_{\mathrm{xy}}$ & $\mathrm{r}_{\text {tabel }}(31)$ & Keterangan \\
\hline Soal 1 & 0,771 & 0,355 & Valid \\
Soal 2 & 0,825 & 0,355 & Valid \\
Soal 3 & 0,788 & 0,355 & Valid \\
Soal 4 & 0,893 & 0,355 & Valid \\
\hline
\end{tabular}

Pada Tabel 2 dapat dilihat bahwa semua soal posttest memiliki nilai $r_{x y}>$ $r_{\text {tabel, }}$, sehingga dapat dikatakan bahwa semua soal valid dan soal-soal tersebut layak untuk digunakan dalam penelitian. 
Selanjutnya uji instrumen adalah uji reliabilitas instrumen, hasil uji reliabilitas soal pretest dapat dilihat pada Tabel 3 berikut:

Tabel 3. Hasil Uji Reliabilitas Pretest

\begin{tabular}{cc}
\hline \multicolumn{2}{c}{ Reliability Statistics } \\
\hline Cronbach's Alpha & N of Items \\
\hline, 886 & 4 \\
\hline
\end{tabular}

Pada Tabel 3 diketahui bahwa nilai dari Cronbach Alpha ada diantara $0,70-0,90$ yaitu 0,886 , sehingga data pretest dapat dikatakan reliable. Selanjutnya, uji reliabilitas instrumen juga dilakukan untuk soal posttest, hasil uji reliabilitas soal posttest dapat dilihat pada Tabel 4 berikut:

Tabel 4. Hasil Uji Reliabilitas Posttest

\begin{tabular}{cc}
\hline \multicolumn{2}{c}{ Reliability Statistics } \\
\hline Cronbach's Alpha & N of Items \\
\hline, 820 & 4 \\
\hline
\end{tabular}

Pada Tabel 4 diketahui bahwa nilai dari Cronbach Alpha ada diantara $0,70-0,90$ yaitu 0,820 , sehingga data posttest dapat dikatakan reliable.

Sebelum diberikan perlakuan kepada kelas kontrol dan kelas eksperimen, kedua kelas tersebut terlebih dahulu diberikan pretest. Uji normalitas data pretest kelas kontrol dan kelas eksperimen bertujuan untuk mengetahui apakah data hasil pretest berdistribusi normal atau tidak. Hasil dari uji normalitas data pretest kelas kontrol dan kelas eksperimen diuji menggunakan Kolmogorov-Smirnov dengan berbantuan SPSS 22.0 for Windows dapat dilihat pada Tabel 5 berikut:
Tabel 5. Hasil Uji Normalitas Pretest

\begin{tabular}{lcccc}
\hline \multicolumn{5}{c}{ Tests of Normality } \\
\hline \multirow{2}{*}{ Kelas } & \multicolumn{3}{c}{ Kolmogorov-Smirnov } \\
\cline { 2 - 5 } & & Statistic & Df & Sig. \\
\hline \multirow{2}{*}{ Nilai } & Kontrol &, 150 & 31 &, 072 \\
\cline { 2 - 5 } & Eksperimen &, 145 & 31 &, 097 \\
\hline a. Lilliefors Significance Correction \\
\hline
\end{tabular}

Pada Tabel 5, diperoleh nilai signifikan untuk kelas kontrol adalah $0,072>0,05, \quad$ sehingga dapat disimpulkan bahwa nilai pretest pada kelas kontrol berdistribusi normal. Sementara nilai signifikan untuk kelas eksperimen sebesar $0,097>0,05$, sehingga dapat disimpulkan bahwa nilai pretest pada kelas eksperimen berdistribusi normal. Berdasarkan hasil signifikansi pretest kelas kontrol dan kelas eksperimen, kedua kelas berdistribusi normal.

Hasil dari uji normalitas data posttest kelas kontrol dan kelas eksperimen diuji menggunakan Kolmogorov-Smirnov dengan berbantuan SPSS 22.0 for Windows dapat dilihat padaTabel 6 berikut:

Tabel 6. Hasil Uji Normalitas Posttest

\begin{tabular}{ccccc}
\hline \multicolumn{5}{c}{ Tests of Normality } \\
\hline \multirow{2}{*}{ Kelas } & \multicolumn{3}{c}{ Kolmogorov-Smirnov ${ }^{\mathrm{a}}$} \\
\cline { 3 - 5 } & Statistic & Df & Sig. \\
\hline \multirow{2}{*}{ Nilai } & Kontrol &, 146 & 31 &, 092 \\
\cline { 2 - 5 } & eksperimen &, 151 & 31 &, 071 \\
\hline
\end{tabular}

a. Lilliefors Significance Correction

Pada Tabel 6 diperoleh nilai signifikan untuk kelas kontrol sebesar $0,092>0,05, \quad$ sehingga dapat disimpulkan bahwa nilai posttest pada kelas kontrol berdistribusi normal. Signifikansi untuk kelas eksperimenn sebesar $0,071>0,05$, sehingga dapat disimpulkan bahwa nilai posttest pada kelas eksperimen berdistribusi normal.

Uji prasyarat selanjutnya adalah uji homogenitas, Uji homogenitas dimaksudkan untuk mengetahui apakah 
nilai pretest kelas kontrol dan kelas eksperimen merupakan data yang homogen atau tidak. Uji homogenitas dalam penelitian ini menggunakan bantuan SPSS 22.0 for Windows berdasarkan uji Levene dengan taraf signifikan $\geq 0,05$. Berikut adalah hasil uji homogenitas pada nilai pretest disajikan pada Tabel 7 berikut:

Tabel 7. Hasil Uji Homogenitas Data Pretest

\begin{tabular}{cccc}
\hline \multicolumn{4}{c}{ Test of Homogeneity of Variances } \\
\hline $\begin{array}{c}\text { Levene } \\
\text { Ntatistic }\end{array}$ & df1 & df2 & Sig. \\
\hline, 801 & 1 & 60 &, 374 \\
\hline
\end{tabular}

Pada Tabel 7, diperoleh nilai signifikan untuk pretestsebesar $0,374>$ 0,05, sehingga dapat disimpulkan jika nilai pretest pada kelas kontrol dan kelas eksperimen tidak ada perbedaan varians.

Setelah dilakukan uji prasyarat berupa uji normalitas dan uji homogenitas, dapat disimpulkan bahwa kelas eksperimen dan kelas kontrol berdistribusi normal dan varian data homogen. Selanjutnya dilakukan uji hipotesis untuk melihat apakah ada pengaruh yang signifikan terhadap kemampuan komunikasi matematis peserta didik setelah diberikan perlakuan yaitu model pembelajaran Learning Cycle 5E pada kelas eksperimen dan model pembelajaran langsung pada kelas kontrol.

Pengujian hipotesis dalam penelitan ini menggunakan uji Independent Sample T-Test dengan bantuan SPSS 22.0 for Windows dengan aturan keputusan, jika sig $>0,05$ maka $\mathrm{H}_{0}$ diterima dan $\mathrm{H}_{1}$ ditolak, sebaliknya jika sig $<0,05$ maka $\mathrm{H}_{0}$ ditolak dan $\mathrm{H}_{1}$ diterima. Adapun perumusan hipotesis dalam penelitian ini adalah:

$\mathrm{H}_{0}$ : Tidak ada pengaruh penggunaan model pembelajran Learning Cycle 5E terhadap kemampuan komunikasi matematis peserta didik.

$\mathrm{H}_{1}$ : Ada pengaruh penggunaan model pembelajran Learning Cycle 5E terhadap kemampuan komunikasi matematis peserta didik.

Berdasarkan uji hipotesis yang dilakukan, diperoleh hasil pada Tabel 8: 
Tabel 8. Hasil Uji Independent Sample T-Test data Posttestpada Kelas Kontrol \& Kelas Eksperimen

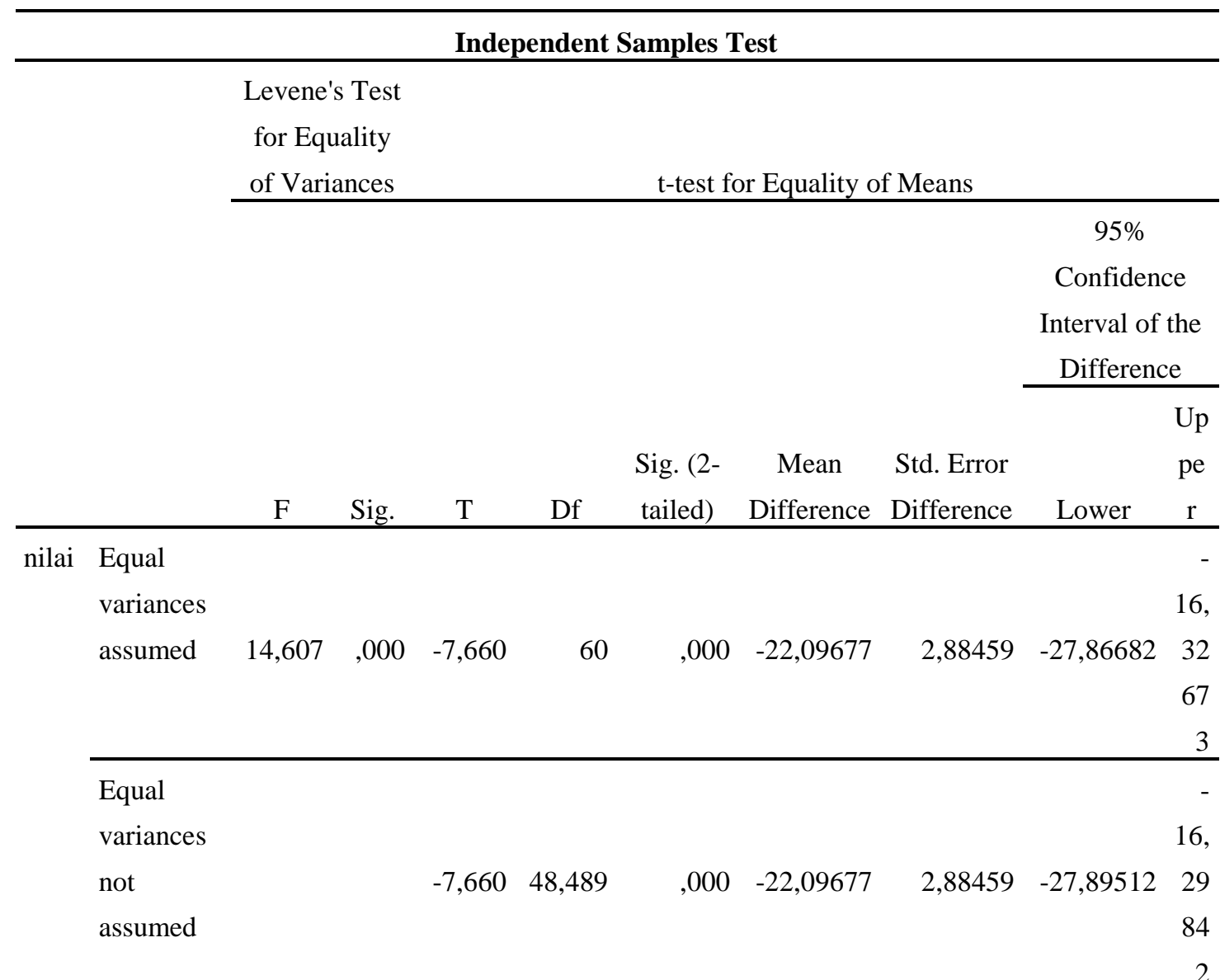

\section{Berdasarkan hasil output SPSS} untuk pengujian hipotesis dengan Independent Sample T-Test diketahui bahwa nilai signifikansi kemampuan komunikasi matematis peserta didik sebesar0,000. Hasil yang dipeoroleh0,000 $<0,05$, maka sesuai dengan aturan pengambilan keputusan dalam uji Independent Sample T-Test. Dengan demikian, bahwa $\mathrm{H}_{0}$ ditolak dan $\mathrm{H}_{1}$ diterima dengan kata lain bahwa ada pengaruh model pembelajaran Learning
Cycle 5E terhadap kemampuan komunikasi matematis peserta didik.

Berdasarkan pengamatan di lapangan selama melaksanakan penelitian serta dari hasil yang diperoleh dari pengolahan data yang telah diuji melalui analisis statistik, dapat disajikan statistik data kemampuan komunikasi matematis peserta didik pada kelas eksperimen dan

kelas kontrol yang dihitung dari data penelitian sesuai Tabel 9. Rentang nilai yang mungkin diperoleh peserta didik adalah antara 0 sampai 100.

Tabel 9. Statistik Data Kemampuan Komunikasi Matematis Peserta didik

\begin{tabular}{ccccc}
\hline \multirow{2}{*}{ Statistik } & \multicolumn{2}{c}{ Kelas Kontrol } & \multicolumn{2}{c}{ Kelas Eksperimen } \\
\cline { 2 - 5 } & Pretest & Posttest & Pretest & Posttest \\
\hline Jumlah Peserta didik & 31 & 31 & 31 & 31 \\
\hline Rata-Rata & 34,51 & 39,39 & 25,74 & 61,49 \\
\hline Nilai Tertinggi & 48,75 & 52,5 & 51,25 & 78,75 \\
\hline Nilai Terendah & 18,75 & 21,25 & 10 & 33,75 \\
\hline
\end{tabular}

Pi: Mathematics Education Journal 
Berdasarkan Tabel 9, terlihat bahwa ratarata nilai tes awal kemampuan komunikasi matematis peserta didik (pretest) kelas kontrol dan kelas eksperimen berbeda. Perbedaan rata-rata nilai dari kedua kelas yaitu sebesar 8,77. Tetapi setelah dilakukan tes akhir kemampuan komunikasi matematis peserta didik (posttest), dapat dilihat jika rata-rata nilai kelas eksperimen lebih tinggi dari kelas kontrol. Selisih rata-rata nilai dari kedua kelas adalah sebesar 22,1. Perbandingan nilai pretest dan posttest dari kelas kontrol dan kelas eksperimen, disajikan pada Gambar 1 berikut:

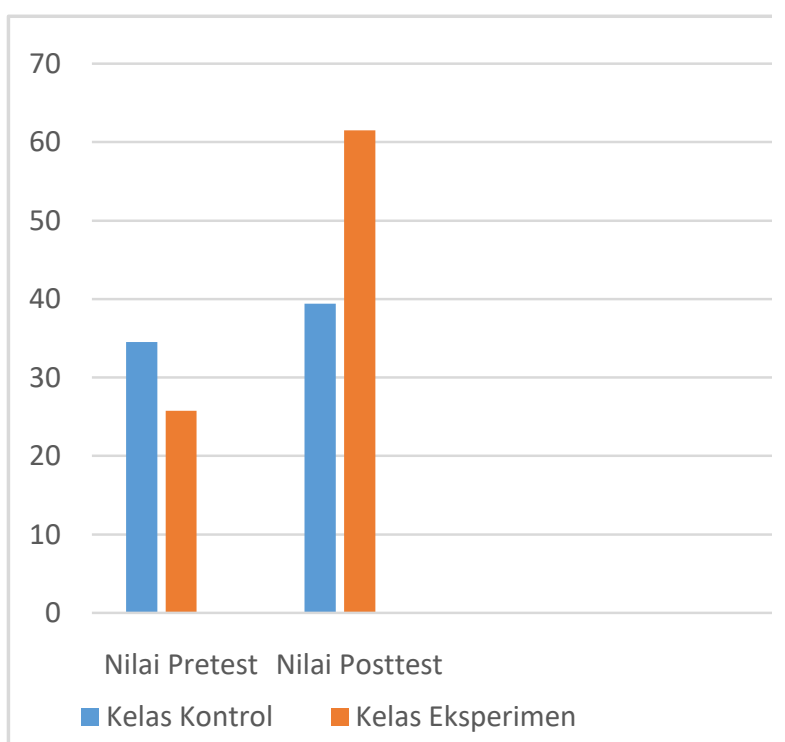

Gambar 1. Rata-Rata Nilai Pretest dan Posttest pada Kelas Kontrol \& Kelas Eksperimen

Pada Gambar 1, terlihat bahwa rata-rata kemampuan komunikasi matematis yang dimiliki oleh peserta didik pada kelas kontrol maupun kelas eksperimen sama-sama mengalami peningkatan. Nilai rata-rata kemampuan komunikasi matematis peserta didik kelas kontrol mengalami peningkatan dari 34,51 menjadi 39,39 dengan selisih peningkatan sebesar 4,88. Nilai rata-rata kemampuan komunikasi matematis peserta didik pada kelas eksperimen juga mengalami peningkatan dari 25,74 menjadi 61,49 dengan selisih peningkatan sebesar 35,75. Dari data tersebut dapat dilihat jika peningkatan pada kelas eksperimen setelah dilakukan perlakuan menggunakan model pembelajaran Learning Cycle 5E lebih tinggi dari pada kelas kontrol yang menggunakan model pembelajaran langsung sehingga dapat dikatakan ada perbedaan yang signifikan pada kelas eksperimen yang menggunakan model pembelajaan Learning Cycle 5E.

Hasil penelitian menunjukkan bahwa nilai akhir (posttest) kemampuan komunikasi matematis peserta didik pada kelas kontrol dan kelas eksperimen terjadi peningkatan kemampuan komunikasi matematis peserta didik pada kelas eksperimen lebih tinggi dari pada peserta didik pada kelas control sehingga dapat dikatakan ada pengaruh penggunaan model pembelajaran Learning Cycle 5E terhadap kemampuan komunikasi matematis peserta didik di SMP Kartika IV-9 Malang. Hal ini sejalan dengan penelitian yang dilakukan oleh Agustyaningrum (2010) yang mengemukakan bahwa implementasi model pembelajaran Learning Cycle 5E dapat meningkatkan kemampuan komunikasi matematis pada peserta didik sebesar $70,11 \%$.

\section{Kesimpulan}

Setelah melakukan analisis data dari hasil penelitian, peneliti telah mendapatkan jawaban dari hipotesis yang sudah dirumuskan. Berdasarkan perhitungan uji Independent Sample TTest dengan taraf signifikan 0,05 diperoleh nilai signifikan $0,000<0,05$. Hal ini menunjukkan bahwa ada perbedaan rata-rata nilai kemampuan komunikasi matematis peserta didik kelas kontrol dan kelas eksperimen, maka dapat ditarik kesimpulan bahwa ada pengaruh model pembelajaran Learning Cycle 5E terhadap kemampuan komunikasi matematis peserta didik. Saran bagi peneliti lain yang ingin melakukan 
penelitian lanjutan mengenai model pembelajaran Learning Cycle 5E untuk menggunakan media untuk lebih mengetahui keefektifan pengguasaan model pembelajaran Learning Cycle 5E pada pembelajaran matematika.

\section{Daftar Rujukan}

Agustyaningrum, Nina. (2010). Implementasi Model Pembelajaran Learning Cycle 5E untuk Meningkatkan Kemampuan Komunikasi Matematis Siswa Kelas IX B SMP Negeri 2 Sleman. Universitas Negri Yogyakarta. (http://eprints.uny.ac.id/73891) diakses tanggal 2 Oktober 2018

Baharuddin, H \& Wahyuni, Esa Nur. (2015). Teori Belajar \& Pembelajaran. Yogyakarta: ArRuzz Media.

Bilgin, dkk. (2013). The Effect of 5E Learning Cycle on Mental Ability of Elementary Students. Journal of Baltic Science Education Vol. 12. (http://journals.indexcopernicus.co m/abstrak.php?icid=1075981) diakses tanggal 28 Nopember 2017

Esny, Cholistiati. (2015). Analisis Kemampuan Komunikasi Matematis Siswa SMP Diponegoro 3 Kedungbanteng. Universitas Muhammadiyah Purwokerto. (http://repository.ump.ac.id/601) diakses tanggal 8 Maret 2018, dari alamat

Fatonah, Siti. (2017). Analisis Kemampuan Komunikasi Matematis Tertulis dalam Penyelesaian Soal Matematika pada Siswa SMP Negeri 03 Malang. Universitas Kanjuruhan Malang.

Irham, Muhammad dan Novan A.W. 2014. Psikologi Pendidikan Teori dan Aplikasi dalam Proses Pembelajaran. Yogyakarta: ArRuzz Media
Lailatus, S.L dan Muhammad A. F. (2016). Pengaruh Model Pembelajaran Learning Cycle terhadap Kemampuan Komunikasi Matematis Siswa dengan Belief Matematika. Universitas Muhammadiyah Tangerang. (http://seminar.uny.ac.id/semnasma tematika/siks/) diakses tanggal 8 Maret 2018, dari alamat

Marsitin, Retno. (2015). Komunikasi Matematik dalam Pembelajaran Program Linier Berkarakteristik Kewirausahaan untuk Menumbuhkan Jiwa Wirausaha Mahasiswa Pendidikan Matematika. Jurnal Pendidikan Matematika, Volume I, Nomor 2, Agustus 2015, Halaman 205-212, ISSN: 2442-4668. (http://riset.unisma.ac.id/index.php/jp $\mathrm{m} /$ article/view/821/810) diakses tanggal 8 Maret 2018, dari alamat

NCTM. (2000). Principle and Standards for School Mathematics. Reston, VA:

NCTM. (http://www.k12academics.com/ed ucation-reform) diakses tanggal 8 Maret 2018, dari alamat

Shoimin, Aris. (2016). 68 Model Pembelajaran Inovatif dalam Kurikulum 2013. Yogyakarta: ArRuzz Media

Sumarmo, U. (2010). Berpikir dan Disposisi Matematika: Apa, Mengapa, dan Bagaimana Dikembangkan Pada Peserta Didik. Bandung: Universitas Pendidikan Indonesia

Suprijono, Agus. (2009). Cooperative Learning. Yogyakarta: Pustaka Belajar

Susanto, Ahmad. (2016). Teori Belajar dan Pembelajaran di Sekolah Dasar. Jakarta: Prenadamedia Group. 